\title{
Interview
}

\section{Interview with Manuel Barcia}

Winner of the Paul E. Lovejoy Prize

Manuel Barcia, the winner of this year's Lovejoy Prize with his new book The Yellow Demon of Fever: Fighting Disease in the Nineteenth-Century Transatlantic Slave Trade (Yale University Press, 202O), is Chair of Global History at the University of Leeds in the UK. Specialized in the history of slavery and the slave trade in the nineteenth-century Atlantic world, he is the author of five books and numerous articles on themes varying from slave resistance in Cuba to the suppression of illegal slave trading on the high seas. The jury members of the Lovejoy Prize were keen to interview him about his work and future research plans.

How did you come to research this particular topic in the first place, and what were your intentions for doing so?

I think that I came across this topic through some sort of serendipitous passageway. For years, while working on the transfers of West African warfare to the Americas, specifically as seen in slave uprisings in places like Cuba and Brazil, I noticed a large number of references to medical matters. Over timeand doing so against the advice that I often give to my own students - I began to write down everything that I thought was worth preserving. After almost two decades of doing so, I realized that I had gathered a significant amount of information and that I had some sort of obligation to do something with it. The way I saw it, I was facing a fork in the road. I could either use all this information to illuminate narratives and discussions at the center of articles I was working on at the time, or I could dive in, immerse myself in the medical history of the Atlantic, and attempt to write a book-length study of disease in the period of the illegal slave trade. As is now plainly obvious, the latter option prevailed. 
I was lucky to have several trailblazing colleagues ahead of me, who made my introduction to the field much smoother. Among them, I could mention James H. Sweet, Londa Schiebinger, Tânia Salgado Pimenta, Katherine Paugh, and Pablo Gomez. I am particularly grateful to Katherine and Pablo, for they advised me when I was still trying to figure out how to frame my questions, and because they also read parts of the book.

How does your study change the way scholars think about (illegal) slave trading in the Atlantic world? What do you hope that students of the Age of Abolition in the Atlantic world will learn or take away from this book?

I think the main thing I would like colleagues to take out of this book is that the struggle against deadly and debilitating diseases in the nineteenth-century illegal slave trade was a story that entailed more collaboration than isolation. Virtually every single document I consulted attested to this. Diseases were a common foe to all of them, and a foe that did not discriminate among them. I also hope my book illustrates the poor conditions experienced by all those associated with this terrible trafficking business. I hope that colleagues can also see how in many ways - and perhaps I could have made this point stronger at times - the "advance" of medical knowledge during the period enabled European colonialism, especially along the African coast.

Finally, I purposedly refused to follow romantic narratives that present white or western medical doctors (or officers, missionaries, etc.) as civilized and enlightened saviors or heroes. Instead, I chose to focus on the day-to-day lives of ordinary people, also attempting to give African practitioners central roles in a story that they helped write just as much as their European and American colleagues did, even if the existing historical sources do not always reflect their contribution.

Your book highlights the multidirectional dissemination of medical knowledge as an important by-product of transatlantic slaving. Could you briefly elaborate for our readers how such dissemination took place, and especially how African medical knowledge influenced European traders' attempts to combat disease?

The issue with the dissemination of African knowledge of any kind during this period is that most of the historical record we have been able to work with was produced by non-Africans, and often by those who sought to enslave and traffic them away. In this book the reader will be able to see a variety of aspects relating to African medical knowledge, including the crucial role of botany, as well as the skillset of many African medical practitioners. Some of the examples I was able to find and incorporate into the book were quite surprising, 
even for me. For example, I was aware that in many parts of Africa, medical practitioners were skillful surgeons, but I was quite taken aback when I found instances of Europeans not only admitting to knowing that, but also yielding to their African colleagues' knowledge, and admitting to learning their surgical methods for procedures - such as the amputation of limbs or the extraction of the guinea worm (dracunculiasis)—from them.

One of the aspects of your book that the committee found especially rewarding is that you consulted source material from such a wide range of historical archives located all over the Atlantic world, including West Africa. Could you tell us a little bit about your experiences conducting archival research in such diverse settings?

As I mentioned before, this book is the result of over two decades of archival work. Over the years, I was able to visit numerous archives all over the Atlantic world, each with its own peculiarities. I should confess here that I was not always able to get all the information I needed at once, and so I also benefitted from the help of colleagues who graciously collected documents I was not able to get myself. In more recent years, I also benefitted from the digitization of various historical archives. Almost everywhere I had the opportunity to visit, I was lucky enough to come across wonderful people who helped me with my research. Having said that, there were some really disappointing moments, such as the time I traveled to an archive abroad only to find out it was closed that week due to a religious holiday, or when I had to wait for almost a year for a few document reproductions from a Spanish archive.

How might your work relate to other studies of slavery and slaving across time and space, beyond the Atlantic world?

The books sits at the confluence of various bodies of scholarship, all of which either directly or tangentially address the history of the transatlantic slave trade. I think that perhaps one of its main features is that, chronologically, it focuses on events that took place after the Danish, British, and other nations began to enforce abolition within their colonies and upon others. The fact that after 1807 , and more poignantly after 1820 , slave dealers throughout the Atlantic began carrying out their human trafficking business in a secretive way, has so far limited the number of medical historical studies about this period, especially when compared with the previous century.

Equally, I think the book reveals how the movement of peoples across the Atlantic and beyond, also contributed to the dissemination of diseases, and to the creation of new disease environments. To a significant extent, I hope that I have been able to show how strategies of hygienic containment fre- 
quently hid an expansionist agenda that can be clearly seen in the ways in which western powers accessed new markets, secured new territories, and controlled new populations. Paraphrasing Alison Bashford, they were able to turn lines of hygienic containment into boundaries of rule, and they did so through diplomatic means or, when required, with the support of their shiny gunboats.

Yourwork not only constitutes a substantial contribution to scholarship on the transatlantic slave trade but also the history of medicine in the modern era, in particular as it relates to international collaboration in combatting disease and the sharing of medical knowledge between continents. What might be the relevance of your research for contemporary society, especially as the world grapples with a global pandemic?

Well, I think that perhaps the main thing I learned while researching and writing this book, is that people and governments have not changed much from the early 1800 s to today. Having said that, I cannot recall coming across a single case of a person during this period who was given the chance of being vaccinated or inoculated against the smallpox, or who refused to do so. I cannot remember any case in which isolation trumped collaboration either. Seeing the Trump administration walking away from the World Health Organization last year, right in the middle of a global pandemic, made me realize how much more invested in collaboration our ancestors were throughout the Atlantic. Even slave traders and those engaged in the suppression of this traffic, were often able to set aside their differences in order to share fragmentary medical knowledge that could save human lives.

I guess having to experience myself the same sort of anxieties and fears that the historical subjects I studied suffered, was an unexpected twist in the story of this book. Very often I found myself comparing stuff I had read in documents with the reality I was living through. Lockdowns, quarantines, vaccines, all, suddenly, became more than a subject of study. There is no doubt that to a certain extent, the advent of CoviD-19 also made the book somehow more relevant to the moment in which it was published.

\section{What will be your next project?}

I am currently working on a new book that will examine the suppression of maritime raiding (read "piracy") around the world between the mid-182os and the late-186os. The comparative scope of this study will hopefully reveal that the suppression of maritime raiding during those years was justified under the banner of spreading civilization and abolishing the slave trade, giving western powers a back door for the development of their colonial ambitions and for the enforcement of free trade. In short, the book will highlight how maritime 
raiding (and its suppression) became a point of contention and collaboration between western and non-western empires, who saw it as an obstacle to their ambitions. Gathering the primary sources for such a study has proven particularly challenging. Firstly, this is because they are written in several different languages, some of which I cannot read; and secondly, because the documents I am using are scattered across the world, housed in more than 20 different countries. In more than one way, this book will be a logical progression for me, as I continue to transition from local history-where I began - towards a more global approach that has-for me at least-become inevitable.

Journal of Global Slavery Editorial Team 